\title{
Economic dispersion of the right of employees to participate in profit sharing payments of companies in Mexico
}

\section{La dispersión económica del derecho laboral a la participación de los trabajadores en las utilidades de las empresas en México}

\author{
OSORIO-ATONDO, José Manuel† \& GASTÉLUM-CELAYA, Danitza María
}

Universidad Estatal de Sonora

ID 1er Author: José Manuel, Osorio-Atondo / ORC ID: 0000-0001-8508-9953, Researcher ID: I-8567-2017

ID 1er Coauthor: Danitza María, Gastélum-Celaya / ORC ID: 0000-0003-1477-4181

DOI: $10.35429 / J L E .2019 .5 .3 .1 .13$

Received August 28, 2019; Accepted December 19, 2019

\begin{abstract}
This research provides a national legal analysis regarding the right to profit sharing of the employees in Mexico, along with the legal basis and the calculation procedure according to what is established in the Political Constitution of the United Mexican States, the Federal Labor Law and the Income Tax Law in the case of legal entities. Likewise, based on descriptive statistics, it also presents the behavior on the manifestation of compliance in filing the annual statement of the tax regime analyzed, as well as the expression of the amounts distributed among their subordinates; with figures issued by the Tax Administration Service (SAT) in its register of taxpayers and data anonymized for fiscal years from 2010 to 2015 . Similarly, in view of the data available from the National Survey of Household Income and Expenditure (ENIGH) for the years 2012, 2014, 2015, 2016 and 2018, there is a wide gap in the dispersion and low income of the income presented.
\end{abstract}

Profit sharing, Labor law, Legal entities

\section{Resumen}

En la presente investigación, se muestra un análisis jurídico nacional en correspondencia al derecho laboral de la participación de los trabajadores en las utilidades de las empresas en México, mostrando en el mismo estudio, su fundamentación jurídica y el procedimiento de cálculo conforme a lo establecido en la Constitución Política de los Estados Unidos Mexicanos, la Ley Federal del Trabajo y la Ley del Impuesto Sobre la Renta para el caso de las personas morales. Asimismo, con base en la estadística descriptiva se exhibe el comportamiento sobre la manifestación del cumplimiento en la presentación de la declaración anual del régimen fiscal analizado, así como la expresión de los montos distribuidos entre sus subordinados; con cifras emitidas por el Servicio de Administración Tributaria (SAT) en su padrón de contribuyentes y datos anonimizados por los ejercicios fiscales del 2010 al 2015. De igual forma, en atención a los datos disponibles de la Encuesta Nacional de Ingresos y Gastos en los Hogares (ENIGH) por los años 2012, 2014, 2015, 2016 y 2018, se ostenta una amplia brecha en la dispersión y bajos ingresos de la percepción económica presentada.

Reparto de utilidades, Derecho laboral, Personas morales

Citation: OSORIO-ATONDO, José Manuel \& GASTÉLUM-CELAYA, Danitza María. Economic dispersion of the right of employees to participate in profit sharing payments of companies in Mexico. Journal-Law and Economy. 2019. 3-5: 1-13.

$\dagger$ Researcher contributing as first author. 


\section{Introduction}

One of the issues mostly addressed in the field of labor law in Mexico is the Participation of Workers in Utilities (EPS), fundamentally highlighting their analysis in their controversies in determining their taxable base, the applicable percentage and the deductibility of the expenditure made by the employer for such concept for tax purposes. However, little or nothing has been examined in correspondence to the distribution of labor law under study from the point of view of compliance by the employer, as well as in its social economic dispersion, much less from the point of view of social inequality.

There are vestiges that the theoretical argument for such a right towards the worker was developed by the German economist Thunen in 1848, later inclined in its application in 1988 by US presidential candidates such as Bruce Babbit and Joseph Biden (Cheadle, sf, cited by Bojórquez, 2007: 250); However, it is argued that such right arises in 1889 at the International Congress of Profit Sharing held in Paris, where it was instituted that in addition to wages and salaries, workers would be entitled to a portion of the profits generated by companies, which are they detached on some basis for their determination (Cynog-Jones, 1956, cited by Bojórquez: 2007: 250), subsequently employed in the other countries prior to establishment in the applicable domestic legal regulations.

In the case that concerns us, both its origin and its structure of such a legal-labor institution of the OCT, we find it in our Political Constitution, developing mainly in the regulatory legal norm called Federal Labor Law (LFT) based on the article 73 of the Magna Carta and which includes what is established in article 123 of the same elementary norm (Borrel, 1988: 265). Precisely in this regard, the present study shows what is related to the OCT in Mexico, showing in the first place the relevance of employment in the economic development of any State, emphasizing the imperative need for labor formality to make effective all labor human rights; showing in this regard data from Mexico issued by federal institutions and agencies.
Then, in order to interpret the legal support of the subject addressed, reference is made to the exegesis of labor law, through doctrinal description and interpretation; showing the legal basis related to the law of the OCT from the fundamental norm and applicable federal laws. Subsequently, with the purpose of explaining the procedure for the determination of the OCT, a hypothetical case is presented in which numerically describes what is established in the regulations with the minimum empirical elements of a legal entity. In the end, the data available in relation to the topic are analyzed, which are issued by the SAT in its open and anonymized data, the figures shown by the National Institute of Statistics and Geography (INEGI) with its instrument applied and identified in its acronym as ENIGH, thereby expressing the social gap or inequality in the distribution of wealth in the labor law analyzed in Mexico.

\section{Employment and economic development}

In any State, the workforce represents an essential factor in its progress and existence as such, since it contributes significantly to economic development, so that in recent decades, governments worldwide have prioritized with greater attention in the job stability and / or growth, building strategies aimed not only at increasing the salary base by incorporating informal employment, but also by improving salary perceptions, social security rights, labor human rights in general and between other factors that contribute to the quality of life of workers and therefore to the progress of the same society.

For this reason, whatever the level of development of a nation, the basis for inducing welfare, inclusion and social cohesion in a sustainable and progressive manner is to have a sufficient supply of jobs, since in the absence of available livelihoods it causes shortages in homes, greater insecurity, decreased human development and economic evolution; that is, the workforce is one of the priorities that must be addressed, which links individuals with the society and the economy in which they live, thus being a substantial element for the progress of people and certifying a sense of belonging to the community by allowing a productive contribution (ILO, nd). 
In this regard, there exists in the economic doctrine a series of classical theories that base its relevance, verbigracia; Orthodox theories stipulate an essential role for the labor market when considering it the regulator par excellence of the economy and therefore the best distributor of resources (Argoti 2011: 39). Also, Smith in his thinking, institutes that the wealth of every society, the set of goods or values that cover the needs and desires of the individuals who form it, assumes its origin in production, by virtue that it is generated and increased by productive activity (Ricoy 2005: 13). In this same position, Sánchez and García (2014: 111), share that "... economic growth is associated with the generation of employment, growing is the best way or strategy to create sources of work, with growth and employment there is income, with them people make purchases, save and invest, leading to a circle of virtuous cumulative causation ", thereby showing the relevance that the State establishes the necessary economic scenario in which there is sufficient supply of employment, contributing thus to the increase of the productive factors of labor and capital. In the case that concerns us, in response to the report to the second quarter of 2019 issued by INEGI with results obtained through the instrument of the National Survey of Occupation and Employment (ENOE), it shows that the economically active population of 15 years or more available for Producing goods and services in Mexico was close to 57 million people, a figure that represented $60 \%$ of the total population in such circumstances; context in which, informal employment - the same that is composed of unprotected work in agricultural activity, domestic service of households and subordinate workers who, despite working for formal economic entities, do so through schemes in which elude registration before social security - added the amount of 30.9 million people (INEGI 2019). Undoubtedly, for employment to have a greater positive effect on the economy of a State and society, it is essential that it arise from a formal employment relationship, by means of which it is established in an individual or collective contract between the parties that intervening called employer and worker, the manifestation of rights and obligations between both; Since there is such a condition, in addition to having an impact on the economy through consumption, family welfare by providing sustenance transcends a series of human rights in the workplace.
With reference to the foregoing and in correspondence with Mexico, one of the instruments used by the government system to indicate said formal relationship between the parties is represented by the data provided by the Mexican Social Security Institute (IMSS), which shows that at At the end of September 2019, there are more than 20.5 million people registered with said social security institute. It is well known that for this formality, the State requires legal norms in which both the rights and obligations between the parties are established, from the labor and social security fields, thereby regulating their performance; by virtue of being the "right to work" a fundamental right to obtain other human rights and thus forming an inherent part of human dignity.

\section{The right to work}

In relation to labor law as a special legal branch, a series of concepts is found in the doctrine for its interpretation of its essential elements such as the object, purpose, nature and scope; same that share congruence in their exegesis and that some of them are described below.

\begin{tabular}{|c|c|}
\hline Autor & Disquisición doctrinal \\
\hline $\begin{array}{l}\text { De la Cueva } \\
(2003: 39)\end{array}$ & $\begin{array}{l}\text { "The right to work in its broadest } \\
\text { acceptance is understood as a freeze of } \\
\text { norms that, in exchange for human } \\
\text { labor, try to realize the right of man to } \\
\text { an existence that is worthy of the } \\
\text { human person" }\end{array}$ \\
\hline Trueba (2003:39) & $\begin{array}{l}\text { "The set of principles, norms and } \\
\text { institutions that protect, dignify and } \\
\text { tend to vindicate all those who live } \\
\text { from their material and intellectual } \\
\text { efforts, for the realization of their } \\
\text { historical destiny: to socialize human } \\
\text { life" }\end{array}$ \\
\hline $\begin{array}{l}\text { Sánchez } \\
(2003: 39)\end{array}$ & $\begin{array}{l}\text { "Labor law is the set of principles and } \\
\text { norms that regulate in its aspects, } \\
\text { individual and collective, the relations } \\
\text { between workers and employers; } \\
\text { between workers among themselves } \\
\text { and between employers, through the } \\
\text { intervention of the state, in order to } \\
\text { protect anyone who provides a } \\
\text { subordinate service, and allow him to } \\
\text { live in dignified conditions, which as a } \\
\text { human being correspond to him so that } \\
\text { he can reach his destiny" }\end{array}$ \\
\hline $\begin{array}{l}\text { De Buen } \\
(2000: 131)\end{array}$ & $\begin{array}{l}\text { "Labor law is a set of norms related to } \\
\text { the relationships that directly or } \\
\text { indirectly derive from the free, } \\
\text { subordinate and remunerated provision } \\
\text { of personal services, and whose } \\
\text { function is to produce the balance of } \\
\text { the factors at stake through the } \\
\text { realization of social justice" }\end{array}$ \\
\hline
\end{tabular}

Table 1 Doctrinal Disquisition of Labor Law Source: own elaboration based on Gómez (2011:11) 
As can be seen, the law of labor is intended to regulate human behavior in society, under the view that such regulations are part of a legal system where its foundation is found in the supreme law or political Constitution; legal norm that is susceptible of necessary adjustments that allow to carry out its regulatory function of the behavior of the town (Pérez 2005: 183). Having made the above considerations, the principle of protection towards the labor force gives the identity and autonomy to labor law in relation to other legal disciplines, requiring state medication through labor legislation whose interpretation is guided by the scoop of protection towards the worker (Padrón et al 2018: 37).

\section{The labor right to Participation in the Profits of Companies in Mexico}

As far as we are concerned, labor rights have their genesis in the Political Constitution of the United Mexican States (CPEUM) of 1917, where such rights are specifically expressed in article 123 of the fundamental law and establishing a series of privileges in favor of the workers and establishing the minimum that should be enjoyed by all those who provide a personal service subordinated to an employer; emerging with it, the discipline called labor law and system in which the legal norm for this purpose is entitled entitled Federal Labor Law (LFT) (SCJN 2005: 5).

For the development of this analysis, it is limited to section A of Article 123 of the CPEUM, a number that the letter indicates in its generalities:

"Article 123. Everyone has the right to decent and socially useful work; for this purpose, the creation of jobs and the social organization of work shall be promoted, in accordance with the law. The Congress of the Union, without contravening the following bases, shall issue laws on labor, which shall govern:"

Section A of the constitutional number referred to above, through a series of fractions, specifies the rights for workers, day laborers, domestic employees, artisans and in a general way; highlighting among them what was established in section IX, which refers to the right to a EPS and indicating its regulation in order in its six subsections.
Based on this premise expressed in the Magna Carta, Chapter VII called "Participation of Workers in the Profits of Companies" in its numbers from 117 to 131 of the LFT, also shows the regulations for the purpose of regulating what concerns to the parties of the labor relationship for the purposes of the distribution of the OCT, the following characteristics being summarized in the first place, where some of them are mentioned in the CPEUM and the LFT.

Workers have the right to the EPS, except in the cases of directors, administrators, general managers, domestic workers and casual workers who have not worked at least sixty days a year. In the case of employees who work in branches or establishments of the same economic entity, they will have the labor law under study.

Similarly, mothers during pre and postnatal periods are considered as active workers, as well as employees who have suffered a work risk during the period of temporary disability.

Regarding the deadlines for the payment of the EPS, it must be done within the sixty days following the date on which the annual tax must be paid, a lien that falls on the Income Tax (ISR) of the fiscal year charged to persons Physical and moral.

Precisely, based on the Income Tax Law (LISR), legal entities are obliged to submit the annual tax declaration mentioned at the latest on March 31 of the year following the corresponding period. manifestation, while, in the same tax legal norm, it is established that natural persons must carry out such obligation no later than April 30.

Therefore, workers who provided subordinate services to legal entities are entitled to receive the EPS in the period from April 1 to May 30 and employees who worked for individuals from May 1 to June 29. Similarly, it is specified in the LFT that the amount of unclaimed profits in the year in which they are enforceable by the workers, will be added to the distributable profit of the following year. 
In addition, the LFT reveals that it exempts from the obligation to distribute profits to newly created companies during the first year of operation, newly installed companies that produce a new product for the first two years of operation; those of extractive industry recently established during the exploration period, private assistance institutions recognized by law, the Mexican Social Security Institute (IMSS), decentralized public organizations for cultural, welfare or charitable purposes and companies that have a smaller capital of the one set by the Ministry of Labor and Social Welfare (STPS) by industry branches. In correspondence to the last case mentioned, the amount of minor capital to exclude these types of companies, the following resolution was issued that states: "They are exempted from the obligation to distribute profits of companies whose capital and labor generate income annual declared to the Income Tax not exceeding three hundred thousand pesos "(Official Gazette of the Federation of December 19, 1996). Together, it is described in the legal norm for this purpose, that the National Commission for the Participation of Workers in the Profits of Companies (CNPTUE), will establish the applicable percentage in the procedure for the determination of the labor law addressed, being carried out for this purpose. adequate research and studies on the general circumstances of the country's economy, taking into account the need to promote industrial development, the right of capital to obtain a reasonable interest, as well as the necessary reinvestment of capital. Based on the last study carried out by said Commission, the percentage in force and which has been maintained for several years is $10 \%$, based on the resolution issued by the Fifth National Commission for the Participation of Workers in the Profits of Companies (Official Gazette of the Federation of February 3, 2009) indicating the following:

"Third. (..) q) To reinforce the issues of the right to capital to obtain a reasonable interest, as well as the necessary reinvestment of capital, some analytical exercises were carried out which, during the period in which the percentage of $10 \%$ has governed derived from the previous Commission, the percentage has had no influence on the economic surplus; that is, that the distribution of profits does not have a negative impact on the benefits that have been presented to date"
However, in attention to the CPEUM and the LFT that indicate that for the determination of the amount of the EPS to be distributed from each company, the taxable income considered also as a utility will be taken as a basis in accordance with the provisions established in the LISR; element on which the aforementioned percentage is applied and thus obtaining the amount to be distributed among its workers who are in such right by the legal fact of the employment relationship as appropriate.

It should be noted that for the purposes of determining the taxable base on which the percentage of the OCT is applied; the procedure for obtaining it varies according to the tax regime in question, in accordance with articles 9 , last and penultimate paragraphs; 109 penultimate and prepenultimate paragraphs, and 111 in its eighth and ninth paragraphs of the LISR; coinciding in the majority of cases in which the taxable income is the one obtained by subtracting from the income obtained in a fiscal year the deductions authorized according to the legal norm mentioned, which are essential for the development of the preponderant activity of the natural or legal person as appropriate. It should be noted that in actual practice, in view of the employer's taxation modality, the taxable base for the purposes of the ISR does not necessarily coincide with that of the OCT, as different elements may intervene in both procedures.

Additionally, the same LFT establishes that once the amount of the EPS has been obtained, it indicates which are the elements to be considered by the company for the purposes of the distribution between the workers and their procedure, which is described in paragraph 123 of the standard labor legal

"Article 123.- The distributable profit will be divided into two equal parts: the first will be divided equally among all workers, taking into account the number of days worked by each one in the year, regardless of the amount of wages. The second will be distributed in proportion to the amount of wages earned for the work provided during the year." 
On the basis of the fundamentals described above, an hypothetical case with respect to the procedure for determining the OCT for purposes of a legal entity is set out as an example, in order to numerically display its obtaining and distribution process among workers with the minimum and most empirically typical elements.

\section{Statement of empirical case regarding the distribution of profits among workers}

For this, suppose the economic entity "Especialidades Comerciales S.A. de C.V.", who shows the following data obtained during fiscal year 2018, elements that are considered in the first place to obtain the taxable base for the calculation of the annual ISR.

\begin{tabular}{|c|c|c|c|c|}
\hline Operation & Concept & Partial I & Partial II & Total \\
\hline & Taxable income & & & $12,780,400.0$ \\
\hline & Authorized & & & \\
\hline & $\begin{array}{l}\text { Cost of what was } \\
\text { sold }\end{array}$ & & $9,622,440.00$ & \\
\hline & $\begin{array}{l}\text { Accrued interest } \\
\text { payable }\end{array}$ & & $11,255.00$ & \\
\hline & $\begin{array}{l}\text { Investment } \\
\text { Deduction }\end{array}$ & & $287,900.00$ & \\
\hline & $\begin{array}{l}\text { Miscellaneous } \\
\text { expense }\end{array}$ & & $982,350.00$ & \\
\hline & Wages: & & & \\
\hline & Taxed & & $893,440.00$ & \\
\hline & Exempt $* *$ & $98,320.00$ & $46,210.40$ & \\
\hline (Less) & Total deductions & & & $11,843,595.4$ \\
\hline (Less) & $\begin{array}{l}\text { OCT paid in the } \\
\text { year }\end{array}$ & & & $198,340.00$ \\
\hline (Same) & Fiscal utility & & & $738,464.60$ \\
\hline (Less) & $\begin{array}{l}\text { Previous Tax } \\
\text { Losses }\end{array}$ & & & $230,420.00$ \\
\hline (same) & Fiscal results & & & $508,044.60$ \\
\hline \multicolumn{5}{|c|}{$\begin{array}{l}\text { **For the alleged case, } 0.47 \text { was applied in accordance with article } 28 \text { section } \\
\text { XXX of the LISR, a number that establishes the factors applicable to the exemp } \\
\text { income paid to workers, since as of the fiscal reform of } 2014 \text { it was established } \\
\text { that for the reason of tax symmetry, only the employer must deduct payment } \\
\text { made to his subordinates who are subject to the same tax, excluding as an } \\
\text { authorized deduction a portion of the income exempt from the tax of employees } \\
\text { and which is then transcribed. }\end{array}$} \\
\hline
\end{tabular}

Table 2 Determination of the taxable base of the ISR. Especialidades Comerciales S.A. from .C.V.

Source: prepared by the author based on the current LISR

"Article 28 (...) XXX Payments that in turn are exempt income for the worker, up to the amount that results from applying the factor of 0.53 to the amount of said payments. The factor referred to in this paragraph shall be 0.47 when the benefits granted by taxpayers in favor of their workers, which in turn are exempt income for said workers, in the fiscal year in question, do not decrease with respect to those granted in the immediate previous fiscal year".
It should be noted that the choice of application by the employer of one of the factors stated in the aforementioned article, obeys what is indicated by rule 3.3.1.29. of the Miscellaneous Fiscal Resolution (RMF) of 2019, heading entitled "Procedure to quantify the proportion of exempt income with respect to total remuneration" (Official Gazette of the Federation of April 29, 2019).

However, according to Table No. 2 above, it exhibits the procedure for the purpose of calculating the taxable base for the determination of the ISR according to its legal norm, which establishes in its Article 9 the process of obtaining the fiscal result and that the letter points:

"Article 9. Legal persons must calculate the income tax, applying the $30 \%$ rate to the fiscal result obtained during the year.

The fiscal result for the year will be determined as follows:

The fiscal utility will be obtained by decreasing all the cumulative income obtained in the year, the deductions authorized by this Title and the participation of the workers in the profits of the companies paid in the year, in the terms of article 123 of the Political Constitution of the United Mexican States.

The fiscal profit of the year will be reduced, where appropriate, the tax losses pending to apply from previous years".

However, to obtain the base of the EPS the same LISR in the penultimate paragraph of the number analyzed above, determines that the share of the profits paid in the year will not be deducted, as well as the tax losses pending to be applied; unlike how the tax base of the ISR is determined. Likewise, in its last statement it stipulates that the income obtained by the workers will be deducted and that they are exempt from the same tax, an element that is not contemplated as a deductible for purposes of the taxable base of the tax mentioned in attention to the fiscal symmetry. 
"Art. $9^{\text {th }}(.$.$) To determine the taxable$ income referred to in subsection e) of section IX of article 123, section A of the Political Constitution of the United Mexican States, the participation of workers in the profits of companies paid in the fiscal year or tax losses pending prior years. For the determination of the taxable income in the matter of participation of the workers in the profits of the companies, the taxpayers must diminish of the accumulable income the amounts that had not been deductible in the terms of the fraction XXX of the article 28 of this Law".

\begin{tabular}{|l|l|l|l|r|}
\hline \multicolumn{1}{|c|}{ Operation } & \multicolumn{1}{c|}{ Concept } & \multicolumn{1}{c|}{ I } \\
& Taxable income & & & $12,780,400.00$ \\
\hline & $\begin{array}{l}\text { Authorized } \\
\text { deductions }\end{array}$ & & & \\
\hline & $\begin{array}{l}\text { Cost of what was } \\
\text { sold }\end{array}$ & & $9,622,440.00$ & \\
\hline & $\begin{array}{l}\text { Accrued interest } \\
\text { payable }\end{array}$ & & $11,255.00$ & \\
\hline & $\begin{array}{l}\text { Investment } \\
\text { Deduction }\end{array}$ & & $287,900.00$ & \\
\hline & $\begin{array}{l}\text { Miscellaneous } \\
\text { expense }\end{array}$ & & $982,350.00$ & \\
\hline & Wages: & & & \\
\hline & Taxed & & $893,440.00$ & \\
\hline & Exempt ** & & $98,320.00$ & \\
\hline (less) & Total deductions & & & $11,895,705.00$ \\
\hline (Same) & EPS Base & & & $884,695.00$ \\
\hline
\end{tabular}

Table 3 Determination of the basis for EPS. Especialidades Comerciales S.A. de C.V.

Source: prepared by the author based on the current LISR

As can be seen, the procedure for determining the taxable base for the purposes of the OCT is different in the case of the ISR, because different elements are involved in the deductions established in the same law. However, starting from the base obtained for EPS and in correspondence to what was founded in the CPEUM and the LFT, the economic entity will have to allocate $10 \%$ on the amount obtained, in this case the figure of $88,469.50$ pesos to be distributed among its workers who have the labor law under study. Returning to the provisions of article 123 of the aforementioned LFT, the amount of the resulting EPS must be separated into two equal parts; where the first takes into account the days worked by the workers and the second in proportion to the amount of wages earned. To illustrate this process, the division of the total amount into two equal parts is presented in the first order and subsequently the relationship of workers with the data required to exemplify the apportionment of the right to the OCT in the alleged case exhibited.

\begin{tabular}{|l|c|c|}
\hline \multicolumn{1}{|c}{ Distribución } & Monto & Total \\
\hline $50 \%$ for working days & $44,234.75$ & \\
\hline $50 \%$ for earned wages & $44,234.75$ & \\
\hline Amount EPS to be distributed & & $88,469.50$ \\
\hline
\end{tabular}

Table 4 EPS distribution. Especialidades Comerciales S.A. de C.V.

Source: own elaboration based on Article 123 of the LFT

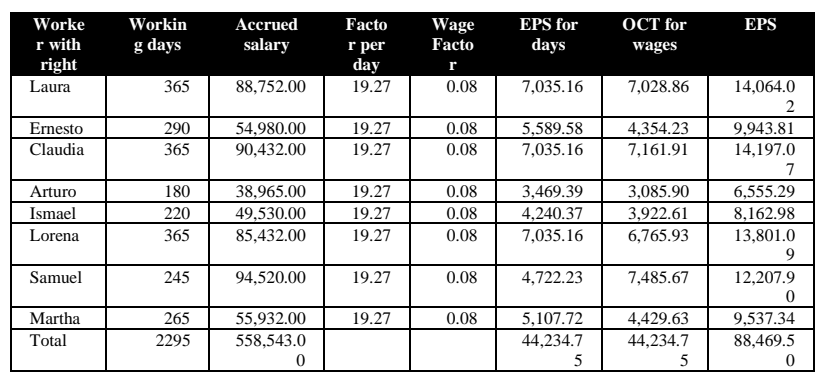

Table 5 EPS cast.Especialidades Comerciales S.A. de C.V.

Source: Own elaboration based on the current LFT

Where:

$$
\begin{aligned}
& \text { Factor per day }=\frac{50 \% \text { PTU }}{\text { total working days }} \\
& \text { Wage Factor }=\frac{50 \% \text { PTU }}{\text { total wages earned }}
\end{aligned}
$$

As can be seen with the example described above, the legal norms applicable to the distribution of the OCT in Mexico, accurately describe both the elements and their treatment for obtaining the labor law in analysis, starting from the fundamental legal norm, the laws with federal scope and the rules issued by the competent authority that contribute to the interpretation of the methodology based on them.

\section{Results of the analysis of the dispersion of the OCT in Mexico}

In the same way, it is clear that the obtaining of income by the worker for the concept of the EPS, in addition to the working conditions of the subordinate to have such a right to work, is subject to the economic behavior of the company, by virtue of the same An economic entity may complete its fiscal year with a fiscal loss and therefore not distribute profits in the following annual period within the established terms by not referring to a EPS base. 
Precisely in this regard, in response to the open data issued by the Tax Administration Service (SAT) and information provided to comply with the Tenth Ninth Temporary Article of the 2017 Income Law, a number that describes as "purpose to contribute to transparency and to the analysis of fiscal policy", makes public the anonymous statistical information of the annual statements of the ISR regarding natural and legal persons.

In the case that corresponds to us in correspondence with the distribution of the OCT, it should be noted that according to the variables shown in the annual statements, only the legal entities exhibit said data in the fiscal years from 2010 to 2015, variable identified in the anonymized data dictionary as "EPS_AA", which defines it as "EPS paid in the year"; where you can see the behavior of taxpayers in the aforementioned tax regime that expressed quantity, zero or no data of the labor law addressed; methodologically identifying and classifying the information for this, where PM = Moral Persons, PM0 = Moral Persons Who Declared Zero, PMCC = Moral Persons With Figures and PMSC $=$ Moral Persons Without Figures. It should be noted that in response to the register of the Federal Taxpayers Registry (RFC) presented by the SAT from 2010 to 2015, it exhibits the data corresponding to legal entities registered before said federal agency.

\begin{tabular}{|r|r|}
\hline \multicolumn{1}{|c|}{ Year } & Moral people \\
\hline 2010 & 1301284 \\
\hline 2011 & 1395392 \\
\hline 2012 & 1486873 \\
\hline 2013 & 1582582 \\
\hline 2014 & 1675028 \\
\hline 2015 & 1763655 \\
\hline
\end{tabular}

Table 6 Register of PM Taxpayers in Mexico 2010-2015 Source: own elaboration with data issued by the SAT

In view of the data shown above and in correspondence with the anonymized ones, it is detected that only 3.7 million, that is to say $40 \%$, of PM presented their annual declaration in the 6 years analyzed, economic entities examined in the following Table, specifically in the heading of EPS.

\begin{tabular}{|c|c|c|c|c|c|c|}
\hline PM & 2010 & $\%$ & 2011 & $\%$ & 2012 & $\%$ \\
\hline PM0 & 127742 & $24 \%$ & 130082 & $23 \%$ & 129992 & $22 \%$ \\
\hline PMCC & 40573 & $8 \%$ & 42239 & $8 \%$ & 43844 & $7 \%$ \\
\hline PMSC & 352312 & $67 \%$ & 387972 & $69 \%$ & 422243 & $71 \%$ \\
\hline Total & 522637 & $100 \%$ & 562304 & $100 \%$ & 598091 & $100 \%$ \\
\hline
\end{tabular}

Table 7 Declaration of EPS by PM in Mexico 2010-2012 Source: own elaboration with open and anonymized data issued by the SAT

\begin{tabular}{|c|c|c|c|c|c|c|}
\hline PM & 2013 & $\%$ & 2014 & $\%$ & 2015 & $\%$ \\
\hline PM0 & 134388 & $22 \%$ & 182700 & $26 \%$ & 154596 & $22 \%$ \\
\hline PMCC & 46512 & $8 \%$ & 49048 & $7 \%$ & 58328 & $8 \%$ \\
\hline PMSC & 435369 & $70 \%$ & 469455 & $67 \%$ & 494289 & $70 \%$ \\
\hline Total & 618282 & $100 \%$ & 703217 & $100 \%$ & 709228 & $100 \%$ \\
\hline
\end{tabular}

Table 8 Declaration of EPS by PM in Mexico 2013-2015 Source: own elaboration with open and anonymized data issued by the SAT

As can be seen in the data mentioned above, a very similar behavior is admitted during fiscal years 2010 to 2015 in correlation with the annual manifestation of the PM in the EPS variable, where the PMSC stands out with the highest percentage, followed by PM0 and with a low percentage of PMCC.

Similarly and rescuing the above described and represented in the case of calculation with the entity "Especialidades Comerciales, S.A. de C.V. ", undoubtedly that the amount to be distributed is subject to the economic behavior of the company since it resides based on the profit obtained; there being a large gap in the monetary perception of the labor law analyzed, since according to figures expressed in the annual statements by the PM, amounts declared by the PMCC of the EPS paid in the fiscal year are exhibited with a large difference between their minimums and maximums presented.

\begin{tabular}{|c|r|r|r|r|}
\hline \multicolumn{1}{|c}{ Variable } & \multicolumn{1}{c}{ PMCC } & \multicolumn{1}{c}{ Minimum } & \multicolumn{1}{c|}{ Maximum } & \multicolumn{1}{c|}{ Mean } \\
\hline EPS 2010 & 40573 & 0.14 & $598,845,069.31$ & $708,006.15$ \\
\hline EPS 2011 & 42239 & 2.19 & $441,516,000.45$ & $735,317.97$ \\
\hline EPS 2012 & 43844 & 4.09 & $1,215,680,961.00$ & $836,711.66$ \\
\hline EPS 2013 & 46512 & 3.27 & $994,454,856.30$ & $797,637.86$ \\
\hline EPS 2014 & 49048 & 1.67 & $776,819,082.00$ & $862,040.88$ \\
\hline EPS 2015 & 58328 & 1.18 & $308,110,541.10$ & $676,078.66$ \\
\hline
\end{tabular}

Table 9 EPS declared by PMCC 2010-2015. Figures in constant pesos

Source: own elaboration with open and anonymized data issued by the SAT 
Once the set of data referring to the EPS declared by the PMCC for fiscal years 20102015 were ordered numerically based on the descriptive statistics, a similar behavior is displayed in the first and third quartiles until 2014 ; Appreciating a decrease in them in the period of 2015, being that there is an approximate increase to $19 \%$ of PMCC that showed the figure of the labor law examined and that was delivered to its workers. Such data conduct suggests that it is due to the change in the EPS calculation procedure based on the fiscal reform that came into force in 2014, thereby contracting the amounts to be dispersed and the scenario that brings congruence with the maximum amount and the average, expressed in 2015 according to Table 8 in which there is a considerable decrease in both statistics.

\begin{tabular}{|l|r|r|r|r|r|r|}
\hline \begin{tabular}{l} 
Statisti \\
\multicolumn{1}{c}{ cal }
\end{tabular} & \multicolumn{1}{c}{ EPS } & \multicolumn{1}{c}{ EPS } & \multicolumn{1}{c|}{ EPS } & \multicolumn{1}{c|}{ EPS } & \multicolumn{1}{c|}{ EPS } & \multicolumn{1}{c|}{ EPS } \\
\hline No. & 40573 & 42239 & 43844 & 46512 & 49048 & \multicolumn{1}{c|}{$\mathbf{2 0 1 5}$} \\
PMCC & & & & & & \\
\hline $1^{\circ}$ & $26,274.7$ & $26,297.3$ & $26,042.1$ & $27,755.4$ & $26,953.1$ & $23,731.4$ \\
Quartile & 5 & 5 & 1 & 7 & 4 & 2 \\
\hline $3^{\circ}$ & $316,810$. & $323,826$. & $322,594$. & $333,466$. & $353,058$. & $275,780$. \\
Quartile & 00 & 89 & 85 & 67 & 34 & 24 \\
\hline
\end{tabular}

Table 10 EPS behavior declared by PMCC in quartiles. 2010-2015 period. Figures in constant pesos

Source: own elaboration with open and anonymized data issued by the SAT

Adding to the above, the data provided by INEGI is relevant through the instrument called the National Survey of Household Income and Expenses (ENIGH), in which the types of economic perceptions that are disclosed are disclosed in the income category they are obtained in households, such as compensation for salaries, overtime, commissions, tips, piecework, bonuses, among others; A total of 81 concepts were classified. In such categorization the income identified by P008 and defined as Profit Sharing for the Year is shown, according to the catalog of income type in the tool applied by the Institute.

After identifying and systematizing the total population surveyed, households that responded to having obtained income from EPS were detected, based on the information presented by the ENIGH 2012, 2014, 2015, 2016 and 2018; where a very wide gap is also shown in the economic perception in the individual under study, aspect that coincides in some areas with the analysis made from the employer's point of view in the PM regime.

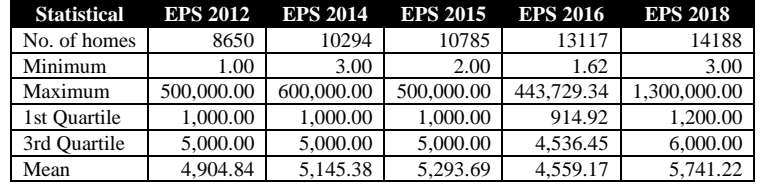

Table 11 EPS revenue according to ENIGH, 2012, 2014, 2015, 2016 and 2018. Figures in Constant Weights.

Source: Own elaboration with data with data obtained in the ENIGH 2012, 2014, 2015, 2016 and 2018

From the above, the low perception in households by the concept of EPS follows, because in the first quartile there is an amount lower than the 13.5 minimum wages in force in the fiscal year that exhibits a better behavior of such remuneration; expressing this scenario on a considerable number of households and in a third quartile where the income is less than or equal to 6,000.00 pesos at best. The income gap in the economic remuneration of the labor law studied and that emerges from several economic elements for its determination and distribution, is visualized in the following graphs, where most of the households concentrate on the low perception in the analyzed concept.

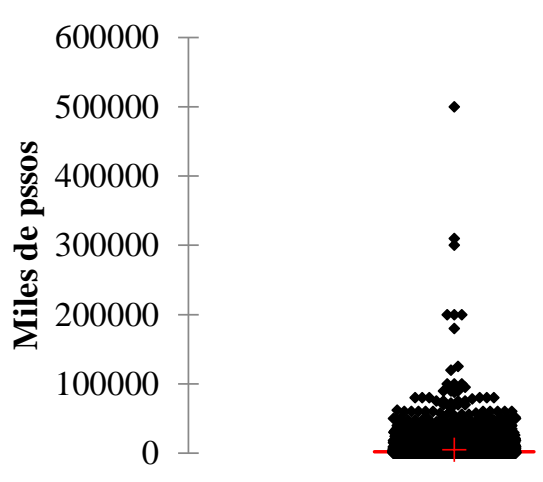

Graphic 1 EPS 2012 dispersion

Source: own elaboration with data obtained in the ENIGH 2012

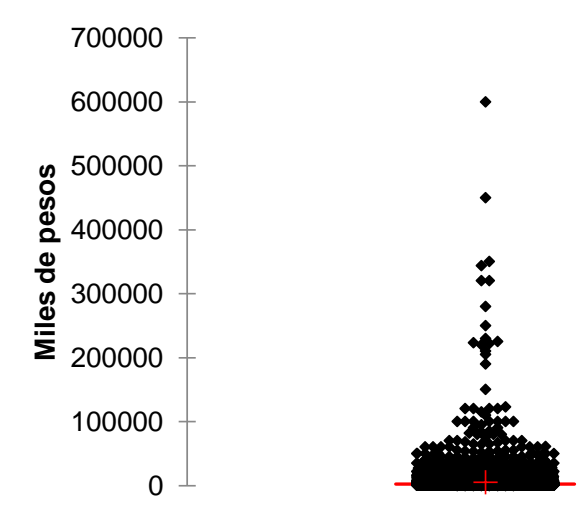

Graphic 2 EPS dispersion 2014

Source: own elaboration with data obtained in the ENIGH 2014 


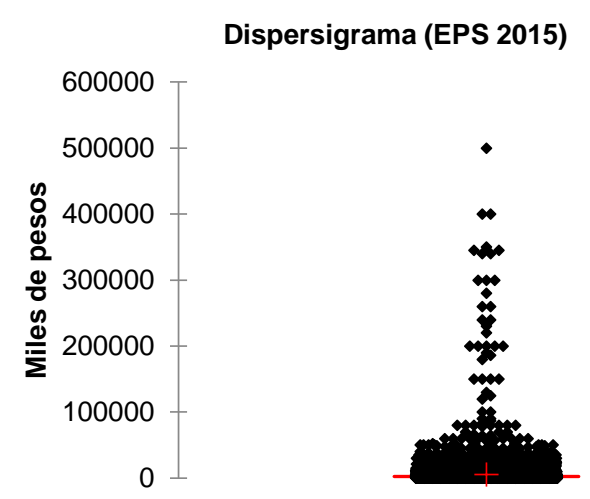

Graphic 3 EPS dispersion 2015

Source: own elaboration with data obtained in the ENIGH 2015

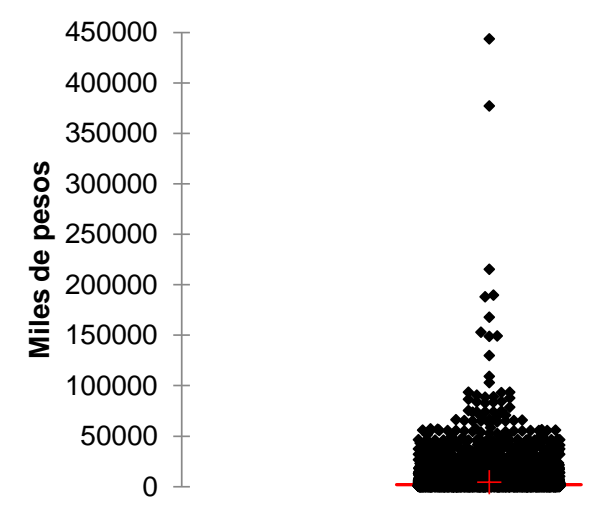

Graphic 4 EPS dispersion 2016

Source: own elaboration with data obtained in the ENIGH 2016

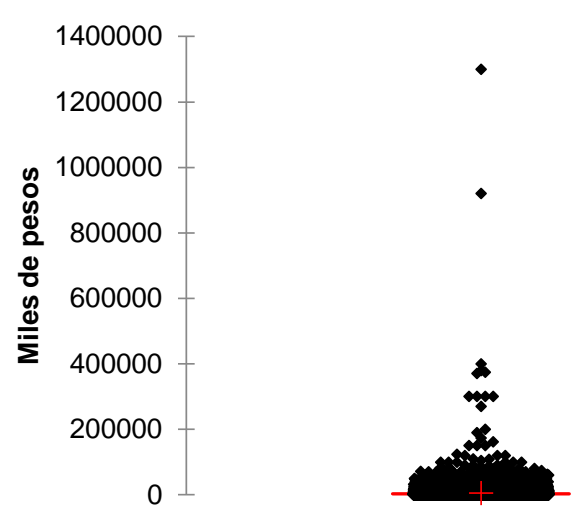

Graphic 5 EPS dispersion 2018

Source: own elaboration with data obtained in the ENIGH 2018

As can be seen in the graphs indicated above, although most of the households fall in a low level of income perception by EPS, there is an improvement in the distribution of the perception in fiscal years 2012, 2016 and 2015 in this order for the dispersed amounts.
It should be noted that the income from EPS expressed in the ENIGH, does not expose the type of legal personality of the employer or tax regime in which it pays, that is, if the remuneration for such concept corresponds to a natural or legal person, as well as the economic sector in which it works.

Similarly, in response to the data obtained in the ENIGH for the years previously analyzed, $50 \%$ of households earn income from EPS with amounts less than two thousand pesos, while $30 \%$ is between two thousand and one. and five thousand pesos and only $20 \%$ receive more than six thousand pesos.

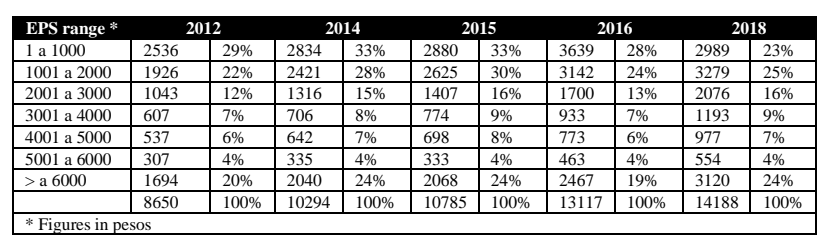

Table 11 Distribution of EPS by ranges in households, according to ENIGH, 2012, 2014, 2015, 2016 and 2018 Source: own elaboration with data with data obtained in the ENIGH 2012, 2014, 2015, 2016 and 2018

\begin{tabular}{|l|r|r|}
\hline \multicolumn{1}{|c|}{ Rango de EPS* } & Cantidad & \multicolumn{1}{c|}{ Total } \\
\hline $\begin{array}{l}\text { Households with EPS from 1 to } \\
1000\end{array}$ & 14878 & $26 \%$ \\
\hline $\begin{array}{l}\text { Households with EPS from } \\
1001 \text { to 2000 }\end{array}$ & 13393 & $24 \%$ \\
\hline $\begin{array}{l}\text { Households with EPS from } \\
2001 \text { to 3000 }\end{array}$ & 7542 & $13 \%$ \\
\hline $\begin{array}{l}\text { Households with EPS from } \\
3001 \text { to 4000 }\end{array}$ & 4213 & $7 \%$ \\
\hline $\begin{array}{l}\text { Households with EPS from } \\
4001 \text { to 5000 }\end{array}$ & 3627 & $6 \%$ \\
\hline $\begin{array}{l}\text { Households with EPS from } \\
5001 \text { to 6000 }\end{array}$ & 1992 & $4 \%$ \\
\hline $\begin{array}{l}\text { Households with EPS Greater } \\
\text { than 6000 }\end{array}$ & 11389 & $20 \%$ \\
\hline Total Households & 57034 & $100 \%$ \\
\hline$*$ Figures in pesos. & & \\
\hline
\end{tabular}

Table 12 Cumulative distribution of EPS by ranges in households, according to ENIGH, 2012, 2014, 2015, 2016 and 2018

Source: own elaboration with data with data obtained in the ENIGH 2012, 2014, 2015, 2016 and 2018 Methodology

For the development of the research, it was based on an exploratory methodology through the study of documentary, descriptive and deductive type; through the examination of legal documents, applicable legislation and specialized files on the subject of analysis and available inquiries on the subject. 
Techniques for locating, fixing and processing data and figures provided by national agencies were used, such as the SAT with the information set out in the PM taxpayers list and their anonymized data in the annual statements by legal entities in the fiscal years from 2010 to 2015, identifying in its data dictionary the variable EPS_AA and conceptualized as "EPS paid in the fiscal year", where the total of PM = Moral Persons was classified and denominated, PM0 = Moral Persons Who Declared Zero, PMCC $=$ Persons Morales With Figures and PMSC $=$ Morales Persons Without Figures. Based on the descriptive statistics, the percentage behavior between the variables, the minimum and maximum declared by the PMCCs and the results in their quarters one and three were identified, as well as the number and percentage of PM that presented annual declaration in relation to the total of the standard.

Likewise, with the information issued by INEGI with its results displayed in the instruments identified in its acronyms as ENOE and ENIGH, referring only figures for the second quarter of 2019 in the first case. While, based on the ENIGH for the years 2012, 2014, 2015, 2016 and 2018, the variable P008 was previously identified in the income type catalog and defined as Profit Sharing for the Year; detecting in attention to descriptive statistics the behavior of household income by concept of EPS, thus exposing the minimum and maximum perception, as well as their quartiles one and three. Similarly, the Graphic design was obtained that shows the dispersion of the EPS for each of the periods. Subsequently, in attention to the third quartile in each of the periods, households were grouped by income ranges, in order to analyze the behavior of perception of EPS less than six thousand pesos. Both databases were treated using the Excel tool with support in the add-on called XLSTAT.

\section{Conclusions}

Based on the analysis, the legal support on the labor law of the workers in the participation of the utilities in Mexico is clearly shown, based on the magna Carta, the federal laws, as well as the rules of the miscellaneous tax, which clearly establish the elements for determination and distribution.
With the present analysis the following findings were made. In the first place, the low compliance is observed in the presentation of the annual declaration of the moral persons, since more than 5.4 million taxpayers of the tax regime under study, in the years from 2010 to 2015 omitted such obligation, thus presuming a scenario tax evasion, which not only affects tax collection, but also the constitutional law of its workers if they have obtained a taxable base for the labor law studied.

Of 3.7 million companies that did submit the declaration during the accumulated and analyzed periods, only 280544 companies, that is, $8 \%$, distributed profits among their workers, while $23 \%$ declared zero in EPS distribution and finally $69 \%$ showed no figure in relation to this concept, exposing the low dispersion of this right of workers in Mexico. It should be noted that of the total population of legal entities that complied in the presentation of their annual declaration, the data of their legal personality type was not located in accordance with the General Law of Commercial Companies (LGSM) to differentiate their corporate purpose , your profit or type of association.

Likewise, in correspondence with the data obtained in the ENIGH 2012, 2014, 2015, 2016 and 2018, they exhibit a wide gap in the dispersion of the EPS in households in Mexico, by virtue that the highest percentage of families obtain lower income at six thousand pesos as obtained in the third quartile in the best scenario. As described in advance, in the variables shown by the aforementioned instrument, the type of economic entity that distributes profits among its workers is not described, that is, it is not clear whether it is a natural or moral person.

Although it is true that the distribution of the EPS is due to the behavior of the economic operations carried out by the companies; However, even if the distribution of profits is a right that assists the worker, it is inferred that most of them do not access this benefit, because in the data provided by the institutions analyzed, the information necessary for discuss the distribution behavior of this concept in a better way. 


\section{References}

Argoti, A. (2011). "Algunos Elementos Sobre la Teoría Clásica del Empleo y la Versión Keynesiana". TENDENCIAS. Revista de la Facultad de Ciencias Económicas y Administrativas. Universidad de Nariño Vol. XII. No. 2, 2do. Semestre 2011, páginas 35-57.

Bojórquez, A. (2007). "Hacia un nuevo Sistema de Reparto de Utilidades". Contaduría y Administración, núm. 221, enero-abril, 2007, pp. 249-274. Universidad Nacional Autónoma de México, Distrito Federal, México.

Borrel, M. (1988). "Participación de los Trabajadores en las Utilidades de las Empresas". Jurídica Anuario del Departamento de Derecho de la Universidad Iberoamericana, No. 19. Instituto de Investigaciones Jurídicas, Universidad nacional Autónoma de México.

Constitución Política de los Estados Unidos Mexicanos. Constitución publicada en el Diario Oficial de la Federación el 5 de febrero de 1917. Última reforma publicada en el Diario Oficial de la Federación el 9 de agosto del 2019. [En línea]. Disponible en: http://www.diputados.gob.mx/LeyesBiblio/pdf/ 1_090819.pdf [Extraída el 24 de octubre del 2019].

Diario Oficial de la Federación (1996). "Resolución por lo que se da cumplimiento a la fracción VI del Artículo 126 de la Ley Federal del Trabajo". Secretaría del Trabajo y Previsión Social. [En línea]. Disponible en: http://www.dof.gob.mx/nota_to_imagen_fs.php $?$ codnota $=4906876 \&$ fecha $=19 / 12 / 1996 \&$ cod_di ario=209868 [Extraído el 28 de octubre del 2019].

Diario Oficial de la Federación (2009). "Resolución del H. Consejo de Representantes de la Quinta Comisión Nacional para la Participación de los Trabajadores en las Utilidades de las Empresas". [En línea]. Disponible en: https://www.dof.gob.mx/nota_to_imagen_fs.ph p?cod_diario $=217789$ \&pagina $=13 \&$ seccion $=2$ [Extraído el 28 de octubre del 2019].
Diario Oficial de la Federación (2019). “Resolución Miscelánea Fiscal para 2019”. [En línea]. Disponible en: https://dof.gob.mx/nota_detalle.php?codigo=55 $58925 \&$ fecha $=29 / 04 / 2019$ [Consultado el 30 de octubre del 2019].

Gómez, R. (2012). "Derecho Laboral I". 1 edición, Red Tercer Milenio S.C., Estado de México, México.

Instituto Mexicano del Seguro Social. "Datos y Recursos". [En línea]. Disponible en: http://datos.imss.gob.mx/dataset/asg-2019 [Consultado el 26 de octubre del 2019].

Instituto Nacional de Estadística y Geografía (2019). "Resultados de la Encuesta Nacional de Ocupación y Empleo. Cifras Durante el Segundo Trimestre de 2019”. [En línea]. Disponible en: https://www.inegi.org.mx/contenidos/saladepre nsa/boletines/2019/enoe_ie/enoe_ie2019_08.pd f [Extraído el 26 de octubre de 2019].

Ley del Impuesto Sobre la Renta. Nueva Ley publicada en el Diario Oficial de la Federación el 11 de diciembre de 2013. Última reforma publicada en el Diario Oficial de la Federación el 30 de noviembre del 2016. [En línea]. Disponible en: http://www.diputados.gob.mx/LeyesBiblio/pdf/ LISR_301116.pdf [Extraída el 26 de octubre del 2017].

Ley Federal del Trabajo. Nueva Ley publicada en el Diario Oficial de la Federación el $1^{\circ}$ de abril de 1970. Última reforma publicada en el Diario Oficial de la Federación el 2 de julio del 2019. [En línea]. Disponible en: http://www.diputados.gob.mx/LeyesBiblio/pdf/ 125_020719.pdf [Extraída el 24 de octubre del 2019].

Organización Internacional del Trabajo (s.f.). "La importancia del empleo y los medios de vida en la agenda para el desarrollo con posterioridad a 2015". [En línea]. Disponible en: https://www.ilo.org/wcmsp5/groups/public/--dgreports/-dcomm/documents/statement/wcms_206443.pd f [Extraído el 25 de octubre de 2019]. 
Padrón, M. et al (2018). “Trabajo y Derechos en México. Nuevas Afectaciones a la Ciudadanía Laboral". $1^{a}$ edición, Instituto de Investigaciones Jurídicas, Serie Doctrina Jurídica, número 35. Universidad Nacional Autónoma de México, México 2018.

Pérez, G. (2005). “Artículo 123 de La Constitución Política de Los Estados Unidos Mexicanos. ¿Inmutable Dinámico?”. Revista Latinoamericana de Derecho Social, núm. 1, julio-diciembre, 2005, pp. 181-184. Universidad Nacional Autónoma de México. Distrito Federal, México.

Ricoy, C. (2005). "La teoría del crecimiento económico de Adam Smith". Economía y Desarrollo, vol. 138, núm. 1, enero-julio, 2005, pp. 11-47. Universidad de La Habana. La Habana, Cuba.

Sánchez, I. y García, R. (2014). "Producción, Empleo Inversión Pública en la Frontera Norte de México". Revista Internacional Administración \& Finanzas (RIAF), volumen 7 No. 7, páginas 111-126.

Servicio de Administración Tributaria. "Datos Anonimizados (Art. Décimo Noveno Transitorio de la LIF para 2017)". [En línea]. Disponible en: http://omawww.sat.gob.mx/cifras_sat/Paginas/i nicio.html [Extraído el 25 de octubre del 2019].

Servicio de Administración Tributaria. "Información para dar cumplimiento al Artículo Décimo Noveno Transitorio de la LIF 2017". [En línea]. Disponible en: http://omawww.sat.gob.mx/cifras_sat/Documen ts/Lineamientos_art\%C3\%ADculo19LIF.pdf [Extraído el 01 de noviembre del 2019].

Suprema Corte de Justicia de la Nación (2005). "Manual del Justiciable. Materia Laboral". $2^{\mathrm{a}}$ edición, Poder Judicial de la Federación, Distrito Federal, México.

Suprema Corte de Justicia de la Nación (2011). "Simetría Fiscal. No es una Garantía Constitucional su Ausencia no Provoca Necesaria y Automáticamente una Transgresión al Artículo 31, Fracción IV, de la Constitución Política de los Estados Unidos Mexicanos".
Semanario Judicial de la Federación y su Gaceta. Novena Época, página 67. Tesis Aislada Constitucional. Tesis: P. LXXVII/2010. Tomo XXXIII, Enero de 2011. [En línea]. Disponible en:

https://sjf.scjn.gob.mx/sjfsist/Paginas/DetalleGe neralV2.aspx $? \mathrm{ID}=162984 \&$ Clase $=$ DetalleT 